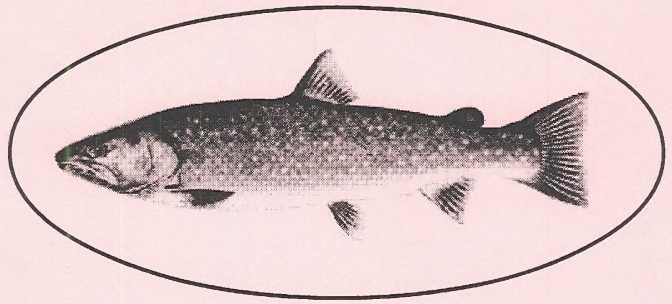

\title{
Status of the Migratory Bull Trout \\ Population in the Jarbidge River Drainage
}

\author{
by \\ Bruce W. Zoellick \\ Robyn Armstrong \\ and Jim Klott
}




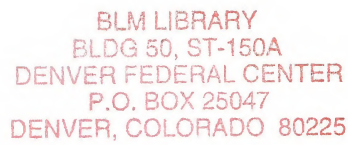

STATUS OF THE MIGRATORY BULL TROUT POPULATION

IN THE JARBIDGE RIVER DRAINAGE

\author{
by \\ Bruce W. Zoellick \\ Bureau of Land Management \\ Lower Snake River District \\ Boise Field Office \\ 3948 Development Avenue \\ Boise, Idaho 83705 \\ Robyn Armstrong ${ }^{1}$ \\ U.S. Fish and Wildlife Service \\ Ecological Services \\ 4696 Overland Road, Room 576 \\ Boise, Idaho 83705 \\ and \\ Jim Klott \\ Bureau of Land Management \\ Lower Snake River District \\ Jarbidge Resource Area Office \\ 2620 Kimberly Road \\ Twin Falls, Idaho 83301
}

${ }^{1}$ Current address of RA: USDA Forest Service, Payette National Forest, McCall, ID 83638 
Abstract: The Jarbidge River drainage in southern Idaho and northern Nevada supports the furthest south population of bull trout (Salvelimus confluentus) in North America. Resident populations of bull trout inhabit the headwaters of the East and West Forks of the Jarbidge River and several tributary streams. A migratory population of bull trout was also thought to be present in the drainage, but surveys conducted in 1992 in the Idaho portion of the Jarbidge drainage, failed to document the presence of migratory bull trout. We resurveyed pools in the middle portion of the Jarbidge River drainage for the presence of migratory bull trout in July 1994 and August 1995, when water temperatures were suitable for bull trout to be present. We observed bull trout in the West Fork of the Jarbidge River in 1994 and in Jack Creek at its confluence with the West Fork in both 1994 and 1995. Minimum population estimates of migratory bull trout in the middle portion of the drainage, based on the number of fish we detected in the length of stream surveyed ranged from 10-20 fish $/ \mathrm{km}$ of stream. We probably did not detect bull trout in the East Fork Jarbidge River because the fish had already moved upstream of our sample reach to more suitable water temperatures. Maximum depth of the pools surveyed in the East and West Forks of the Jarbidge River averaged 1.0 and $0.9 \mathrm{~m}$, respectively. Many pools also had fairly complex habitat structure formed by boulders and woody debris, indicating both streams provided suitable habitat for migratory bull trout. Two tributary streams, Dave and Deer Creeks, did not appear suitable for migratory bull trout except as movement corridors; maximum pool depths averaged just 0.3 to $0.5 \mathrm{~m}$. During the surveys for bull trout we also collected information on the distribution and abundance of other native fish species. Redband trout (Oncorhynchus mykiss gairdneri) were the most widely distributed and abundant fish in the drainage.

\section{Introduction}

The bull trout (Salvelimus confluentus) is a $\mathrm{C} 1$ candidate for listing as endangered (Federal Register 58(93):28849-52). The greatest risks facing bull trout are habitat loss and degradation and the isolation of populations (Federal register 58(93):28849-52). The Jarbidge River drainage in southern Idaho and northern Nevada has the furthest southern population of bull trout. Bull trout were formerly found further south in the McCloud River drainage in California, but that population has been extirpated (Rode 1988). The Jarbidge River population is isolated from the nearest adjacent populations in the Boise River drainage in south-central Idaho.

In 1992, in a cooperative study with the U.S. Bureau of Land Management (BLM), the Idaho Fish and Game Department (IDFG) surveyed the Jarbidge River in southern Idaho to determine the status of bull trout in the Idaho portion of the Jarbidge River drainage (Warren and Partridge 1993). Resident populations of bull trout were known to inhabit the upper portions of both the East Fork and West Fork drainages in Nevada (Johnson 1990). Because of the large size of some of the fish caught in Nevada and occasional reports of bull trout being caught in the mainstem of the Jarbidge River in Idaho, both nonmigratory and migratory populations of bull trout were thought to be present in the Jarbidge River system (Warren and Partridge 1993). Flows at the time of the IDFG survey in 1992 were among the lowest on record and stream 
temperatures had increased more rapidly than usual. No bull trout were detected during the 1992 inventory; which left unanswered the questions of whether the fish had already moved to stream reaches at higher elevations (and consequently cooler water temperatures) at the time of the survey, or whether migratory bull trout were no longer present in the Jarbidge River system.

Conservation of bull trout populations requires maintenance of multiple local populations (Rieman and McIntyre 1993). Because the Jarbidge River population is on the southern periphery of the range of the bull trout, environmental conditions are probably more variable than in the central portion of its range. The presence of several subpopulations increases the probability that at least one will survive periods of disturbance. In particular, migratory populations may be very important for stabilizing populations in highly variable environments or refounding segments of populations that become extinct. This diversity in life histories is thought to be an important mechanism in the persistence of bull trout in variable environments (Rieman and McIntyre 1993). For this reason, we examined if migratory populations of bull trout were still present in the Jarbidge River drainage.

\section{Study Objectives}

The primary objective of this study was to resurvey stream segments sampled by Warren and Partridge (1993) when water temperatures were favorable for migratory bull trout to be present. We wanted to determine if migratory fish were still present in the drainage and using portions of the Jarbidge River and tributary streams on BLM managed lands. A second objective was to collect baseline data on pool size and depths of streams in the Jarbidge drainage that might be migratory corridors for bull trout. A final objective was to collect information on the distribution and abundance of other fish species encountered during surveys for bull trout. The middle section of the Jarbidge River drainage in southern Idaho and northern Nevada was surveyed for bull trout in a cooperative effort by the BLM, U.S. Fish and Wildlife Service (USFWS), and U.S. Forest Service (USFS) Intermountain Research Station in March and July 1994, and August 1995.

\section{Study Area}

The Jarbidge River watershed is approximately 1,720 square $\mathrm{km}$ in size (Warren and Partridge 1993). The headwaters of the East and West Forks of the Jarbidge River are located at an elevation of about $3,200 \mathrm{~m}$ in the Jarbidge Mountains in northern Nevada. The East and West Forks are 36 and $32 \mathrm{~km}$ long, respectively, and flow north into Idaho (Fig. 1). The confluence of East and West Forks of the Jarbidge River is located about $5.8 \mathrm{~km}$ north of the Idaho-Nevada border at an elevation of $1,518 \mathrm{~m}$. From the confluence of the Forks the mainstem flows northwesterly about $45 \mathrm{~km}$ to the Bruneau River at an elevation of $1,128 \mathrm{~m}$. 
Figure 1. Areas surveyed for migratory bull trout in the middle portion of the Jarbidge River drainage in southern Idaho and northern Nevada, 1994-95.

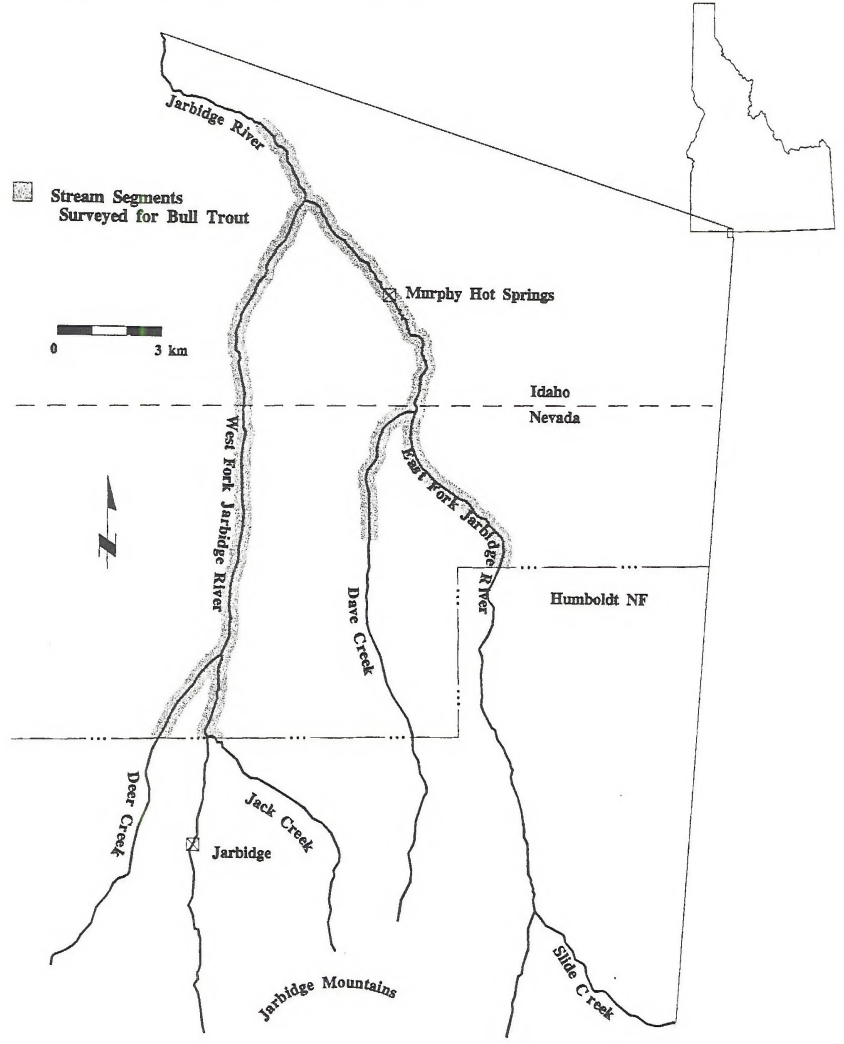


A dirt road parallels the East Fork of the Jarbidge River from its confluence with the West Fork $4.0 \mathrm{~km}$ upstream to the town of Murphy Hot Springs. Above Murphy Hot Springs, the stream flows through a narrow rhyolitic canyon with no roads and developments. The West Fork of the Jarbidge has a road paralleling it from the confluence of the Forks upstream $25.1 \mathrm{~km}$ to the Jarbidge Wilderness boundary. The town of Jarbidge is located on the West Fork $13.9 \mathrm{~km}$ upstream of the Nevada state line. The West Fork of the Jarbidge River in the vicinity of Jarbidge was placer mined in the 1880 's. The lower to middle portions of the Jarbidge drainage are located on lands managed by the BLM. The upper one-third of the drainage, starting 13.6 and $16.7 \mathrm{~km}$ up the East and West Forks, is primarily located on lands managed by USFS, including most of the tributary streams known to support resident populations of bull trout.

\section{Methods}

Electrofishing Surveys.--BLM biologists sampled 4 sites on the East and West Forks of the Jarbidge River using a Smith-Root Model 15-A backpack electroshocker on March 16-17, 1994. Three of Warren and Partridge's (1993) sample sites were resampled (Sites 17 and 19 on the West Fork of the Jarbidge, and Site 13 on the East Fork). Additionally, we sampled the East Fork Jarbidge upstream of the town of Murphy Hot Springs at stream mile 3.5 (upstream of the confluence of the two forks). The sample sites were approximately $100 \mathrm{~m}$ long.

The length of stream sampled was measured at each site and average stream width was calculated from three measurements of stream width taken at the top, middle, and bottom of the sample reach to use to calculate fish population densities. We made three electrofishing passes, capturing and segregating fish from each pass. All fish were measured to the nearest $\mathrm{mm}$; and redband trout (Oncorhynchus mykiss gairdneri) (Behnke 1992) were weighed to the nearest gram before they were released. Redband trout population sizes were estimated using the Zippin removal model (Zippin 1958).

Snorkel Surveys,--Biologists with the BLM, USFWS, and USFS Intermountain Research Station visually surveyed for the presence/absence of bull trout by snorkeling on July 5-8 and 1214,1994 . We attempted to time the surveys when flows had dropped from spring runoff levels so that visibility was good, but before water temperatures increased. We snorkeled a total of 56 pools and $1158 \mathrm{~m}$ of stream in the mainstem, East Fork, and West Fork of the Jarbidge River, and tributary streams Dave Creek and Jack Creek (Fig. 1). In August 1995, we snorkeled 12 sites totaling $102 \mathrm{~m}$ of stream on Deer Creek, which is tributary stream to the West Fork of the Jarbidge River. We also resurveyed a pool at the lower end of Jack Creek downstream of the road to Jarbidge.

Pools were selected to survey based on their habitat quality (woody debris or boulder complexes), while spacing the sites to systematically sample BLM managed lands in Idaho and Nevada. As water temperatures increased in the second week of field work in 1994, we concentrated our sampling at the upper end of BLM managed lands in the Jarbidge drainage. 
Pools were surveyed by two observers snorkeling side-by-side and moving upstream through each sample site (Thurow 1994). Six pools were snorkeled at night with a dive light to check if the composition of fish species observed differed between day and night surveys. Air and water temperatures were measured with a hand-held thermometer at each sample site. Basic channel morphology measurements (length, width, maximum and tail depth) were recorded for pool sites.

Results

Electrofishing Surveys.--Species collected at the four sites sampled in March 1994 included redband trout, speckled dace (Rhinichthys osculus), mountain whitefish (Prosopium williamsoni), sculpin (Cottus bairdi), and bridgelip sucker (Catostomus columbianus) (Table 1). We did not sample any bull trout. The range of redband trout densities observed (Table 1) was similar to that found by in 1992 by Warren and Partridge (1993). However, when specific sites were compared, our redband densities were generally lower than those observed by Warren and Partridge (1993) (Table 2).

Table 1. Redband trout population estimates and densities for sites in the East and West Forks of the Jarbidge River and counts of other species sampled by electrofishing in March, 1994.

\begin{tabular}{|c|c|c|c|c|c|c|c|}
\hline \multirow[b]{2}{*}{ Site } & \multirow{2}{*}{$\begin{array}{l}\text { Population } \\
\text { Estimate }\end{array}$} & \multirow[b]{2}{*}{ SE } & \multirow{2}{*}{$\begin{array}{l}\text { Density } \\
\text { (fish } / \mathrm{m}^{2} \text { ) }\end{array}$} & \multicolumn{4}{|c|}{ Number of Other Fish Sampled } \\
\hline & & & & $\begin{array}{l}\text { Speckled } \\
\text { Dace }\end{array}$ & $\begin{array}{l}\text { Mottled } \\
\text { Sculpin }\end{array}$ & $\begin{array}{l}\text { Bridgelip } \\
\text { Sucker }\end{array}$ & $\begin{array}{l}\text { Mountain } \\
\text { Whitefish }\end{array}$ \\
\hline \multicolumn{8}{|c|}{ East Fork Jarbidge River } \\
\hline Mile 0.6 & 36 & - & $5.7^{1}$ & 16 & 64 & 3 & 1 \\
\hline Mile 3.5 & 39 & 10.34 & 3.8 & 8 & 46 & 0 & 0 \\
\hline \multicolumn{8}{|c|}{ West Fork Jarbidge River } \\
\hline Mile 0.6 & 29 & 2.96 & 4.0 & 17 & 24 & 0 & 0 \\
\hline Mile 3.4 & 11 & 0.33 & 1.5 & 3 & 7 & 0 & 0 \\
\hline
\end{tabular}

We probably underestimated redband trout densities, as flows were at or above the levels we could effectively sample with the backpack shocker; we occasionally observed fish leaving the field or being swept downstream. Additionally, the trout could have been distributed differently during the spring flows which were considerably higher than flows during summer 1992 when IDFG conducted their sampling. 
Table 2. Comparison of redband trout densities and population estimates for sites electrofished in the East and West Forks of the Jarbidge River in July-August 1992 and March 1994.

\begin{tabular}{|c|c|c|c|c|c|}
\hline Site & Year & $\begin{array}{c}\text { Stream } \\
\text { Length }(m)\end{array}$ & $\begin{array}{c}\text { Population } \\
\text { Estimate }\end{array}$ & SE & $\begin{array}{c}\begin{array}{c}\text { Density } \\
\text { (fish } / 100 \mathrm{~m}^{2} \text { ) }\end{array}\end{array}$ \\
\hline \multicolumn{6}{|c|}{ East Fork Jarbidge River } \\
\hline \multirow{2}{*}{ IDFG $13^{1}$} & 1994 & 88 & $36^{2}$ & - & 5.7 \\
\hline & 1992 & 112 & 120 & 92.98 & 16.2 \\
\hline Mile 3.5 & 1994 & 114 & 39 & 10.34 & 3.8 \\
\hline \multicolumn{6}{|c|}{ West Fork Jarbidge River } \\
\hline \multirow[t]{2}{*}{ DFG 17} & 1994 & 91 & 29 & 2.96 & 4.0 \\
\hline & 1992 & 113 & 50 & 21.21 & 6.1 \\
\hline \multirow[t]{2}{*}{ IDFG 19} & 1994 & 96 & 11 & 0.33 & 1.5 \\
\hline & 1992 & 115 & 48 & 9.81 & 5.6 \\
\hline
\end{tabular}

${ }^{1}$ The 1992 data and site selection is from sampling conducted by Idaho Fish and Game Department (IDFG) (Warren and Partridge 1993).

${ }^{2}$ Minimum population estimate; we were unable to calculate an estimate using the removal model because of unequal capture probabilities between runs.

Snorkel Surveys.-- We surveyed 5 pools on the mainstem Jarbidge River at an elevation of about $1518 \mathrm{~m}$, covering approximately the first $2.1 \mathrm{~km}$ downstream of the confluence of the East and West Forks (Fig. 2). Water temperatures in the mainstem Jarbidge River had already increased to 16 degrees $\mathrm{C}$ during the afternoon on July 5 when we started the snorkel surveys. Therefore, we concentrated our sample efforts further up the drainage where water temperatures were more suitable for bull trout.

We sampled 14 pools on the East Fork of the Jarbidge over approximately $13.6 \mathrm{~km}$ of stream (elevations ranged from 1518 to $1715 \mathrm{~m}$ ) (Figs. 2 and 3). On the West Fork Jarbidge, we surveyed 26 pools over a $16.7 \mathrm{~km}$ length of the stream from the mouth of the stream upstream to the BLM-Forest Service boundary (elevations ranged from 1518 to $1801 \mathrm{~m}$ ) (Figs. 2 and 4). We also sampled 10 pools in Dave Creek at elevations of 1798 to $1878 \mathrm{~m}$ (Fig. 4) and one pool in Jack Creek at an elevation of $1792 \mathrm{~m}$ (Fig. 3). Additionally, we sampled two segments on the upper West Fork of the Jarbidge River in 1994 just upstream of the confluence with Pine Creek and at the Jarbidge Wilderness Boundary at elevations of 2030 to $2057 \mathrm{~m}$. In 1995, we resampled the pool in Jack Creek and sampled 12 pools or pool-riffle complexes in a $0.3 \mathrm{~km}$ segment of Deer Creek at an elevation of about $1950 \mathrm{~m}$ (Fig. 3). We sampled a total of $1158 \mathrm{~m}$ of stream in 1994 (Table 3), and $102 \mathrm{~m}$ of Deer Creek in 1995. 
Figure 2. Location of sites surveyed for bull trout by electrofishing and snorkeling on the East and West Forks of the Jarbidge River and the Jarbidge River downstream of the Idaho-Nevada border, March and July 1994.

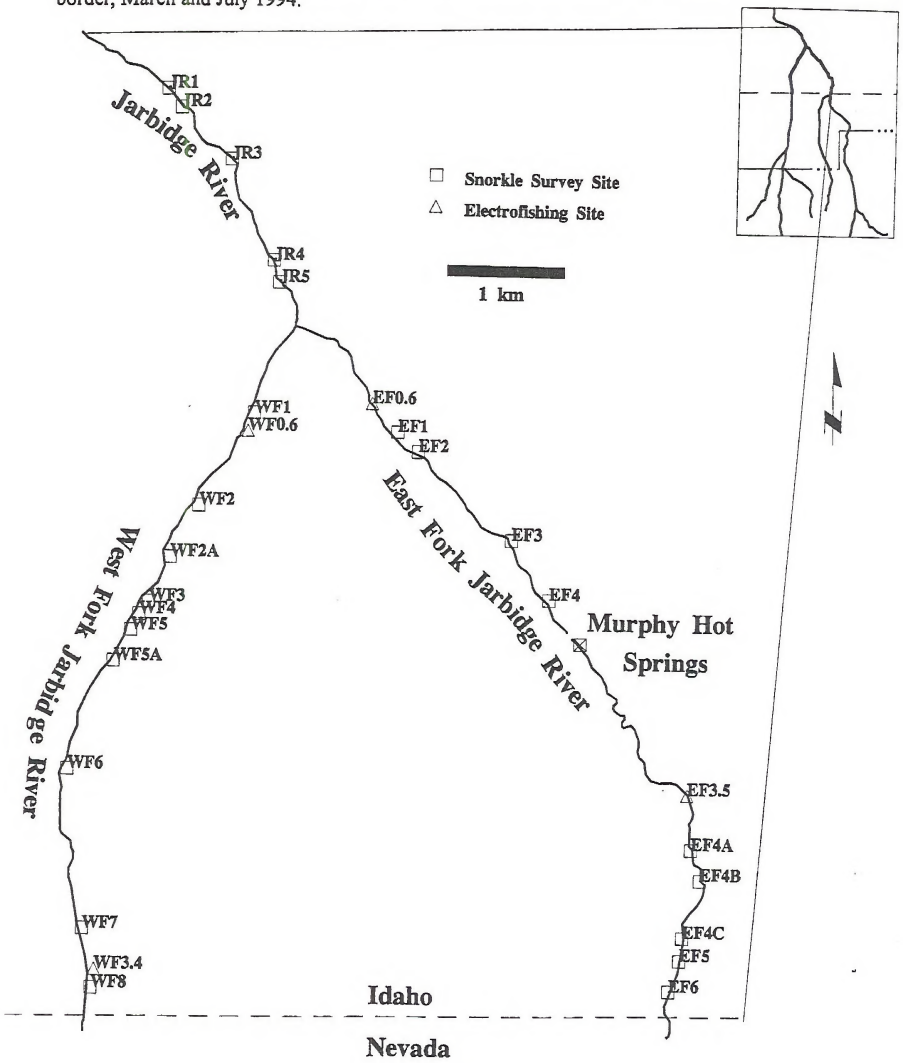


Figure 3. Location of sites surveyed for bull trout by snorkeling on the East Fork Jarbidge River and Dave Creek upstream of the Idaho-Nevada border, July 1994.

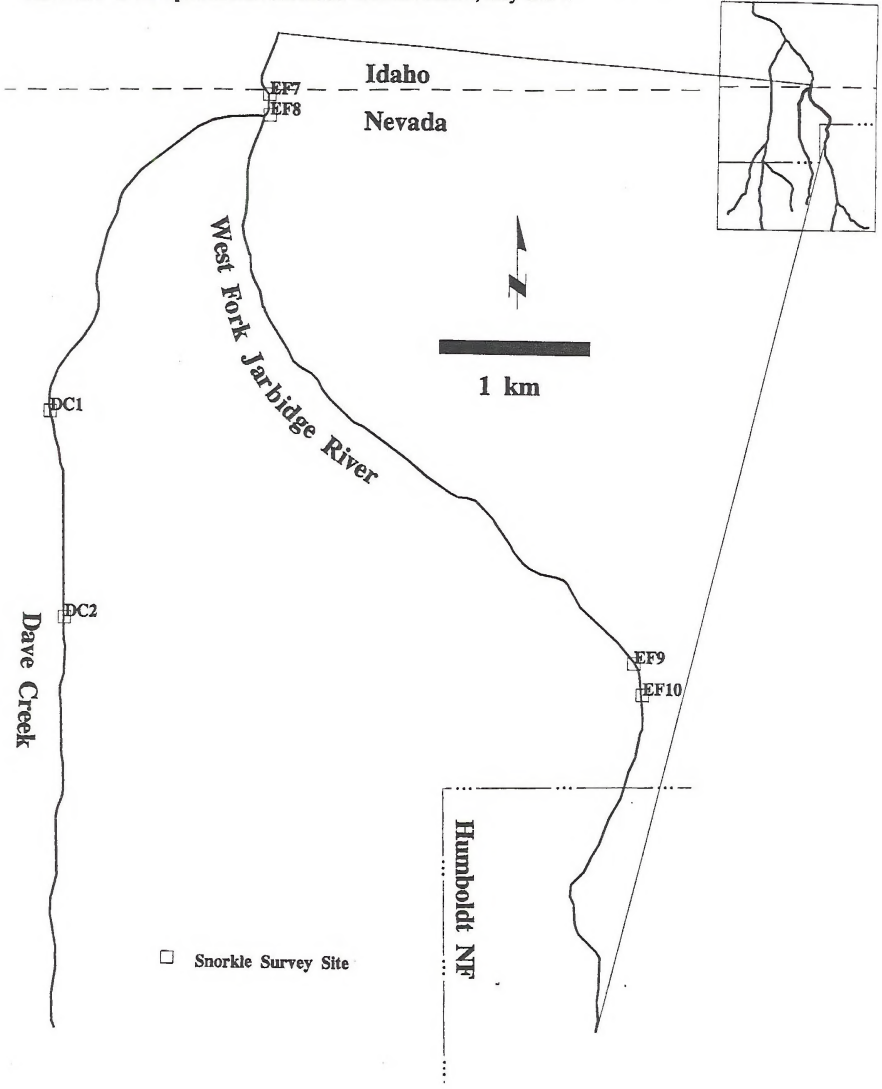


Figure 4. Location of sites surveyed for bull trout by snorkeling on the West Fork Jarbidge River, Deer Creek, and Jack Creek upstream of the Idaho-Nevada border, July 1994 and August 1995.

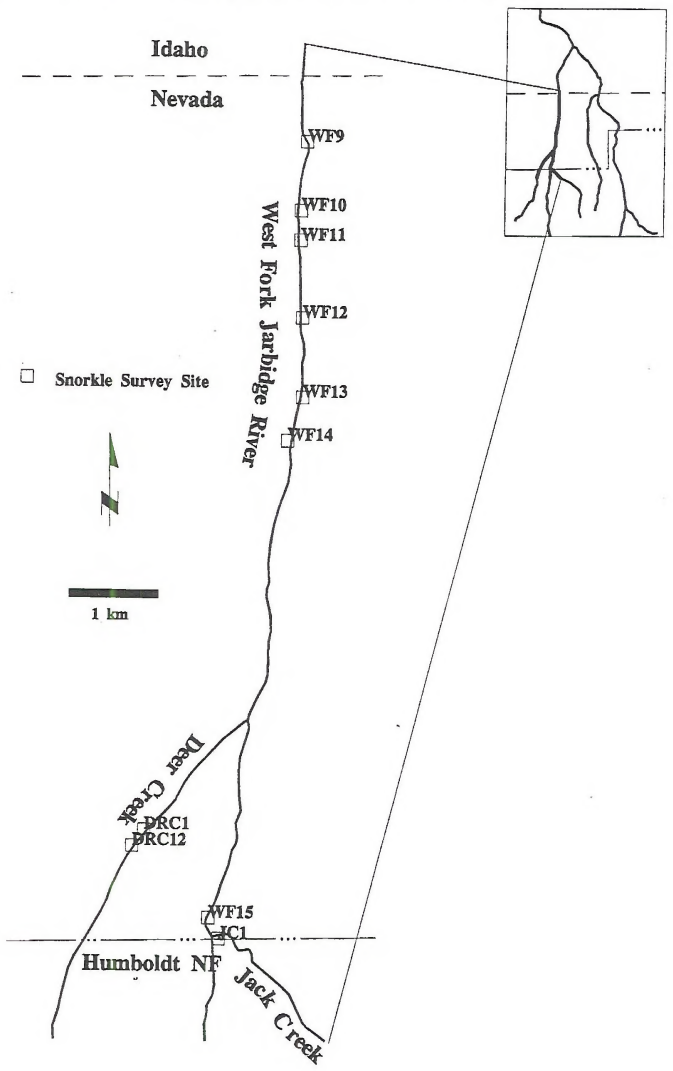


In 1994, afternoon water temperatures on the East Fork increased from an average of 13.9 degrees $C$ during July 5-8 to 17.2 degrees $C$ during July $12-14$. Similarly, water temperatures on the West Fork during the afternoon increased from an average of 14.9 degrees $C$ on July 5-8 to 16.9 degrees $C$ on July 12-14. Average water temperatures for all sample sites and times of the day are presented in Table 3. Afternoon water temperatures on August 7 and 8, 1995 on the West Fork of the Jarbidge were slightly lower (about 1 degree $\mathrm{C}$ ) than they were a month earlier in the year in 1994, showing the significant effect of low flows on water temperatures during summer 1994. Average stream flows in the Bruneau-Jarbidge River drainage in 1995 were more than double 1994 stream flows (Fig. 5).

Table 3. Lengths of streams inventoried for bull trout and average water temperatures during the surveys conducted by snorkeling, Jarbidge River drainage, July 5-12, 1994.

\begin{tabular}{lcc}
\hline \multicolumn{1}{c}{ Stream } & $\begin{array}{c}\text { Total Length } \\
\text { Sampled (m) }\end{array}$ & $\begin{array}{c}\text { Mean Water } \\
\text { Temperature } \\
\text { (Celsius) }\end{array}$ \\
\hline Jarbidge River & 199 & 13.8 \\
East Fork Jarbidge & 334 & 13.8 \\
West Fork Jarbidge & 555 & 13.8 \\
Dave Creek & 65 & 9.2 \\
Jack Creek & 5 & $13.9^{1}$ \\
\hline
\end{tabular}

${ }^{1}$ Temperature of Jack Creek was measured only on July 12,1994 at $6: 18 \mathrm{pm}$, when the water temperature in the W. Fork Jarbidge River was 18.3 degrees $\mathrm{C}$.

In 1994, we observed bull trout at two sites: a single bull trout (approximately $175 \mathrm{~mm}$ in length) at site 6 on the West Fork of the Jarbidge River, approximately $2.4 \mathrm{~km}$ downstream of the Idaho-Nevada border at an elevation of $1591 \mathrm{~m}$, and 5 bull trout (size range approximately 175 to $225 \mathrm{~mm}$ ) in Jack Creek at its confluence with the West Fork of the Jarbidge approximately $9.6 \mathrm{~km}$ upstream of the Idaho-Nevada border at an elevation of $1792 \mathrm{~m}$ (Table 4, Fig. 4). The fish in Jack Creek were in the plunge pool formed by the lower end of the culvert for the road to the town of Jarbidge that parallels the West Fork of the Jarbidge. In 1995, we did not observe any bull trout in Deer Creek, but we did observe one bull trout (about $225 \mathrm{~mm}$ in length) again in the plunge pool below the culvert on Jack Creek. We did not observe any bull trout in $111.5 \mathrm{~m}$ of stream surveyed in 1994 on the upper West Fork of the Jarbidge River at the Jarbidge Mountain Wilderness boundary (bull trout at the elevation of the Wilderness boundary would presumably be resident fish).

Species composition of fish observed during the night and during the day did not differ. Native redband trout were by far the most commonly observed fish. Every pool surveyed, except for one in Dave Creek, had redbands present (Tables 4 and 5). All 12 sites surveyed in 
Figure 5. Average annual stream flows for the Bruneau River from 1986 to 1995 , compared to the long term average flow. The Jarbidge River is a major tributary to the Bruneau River.

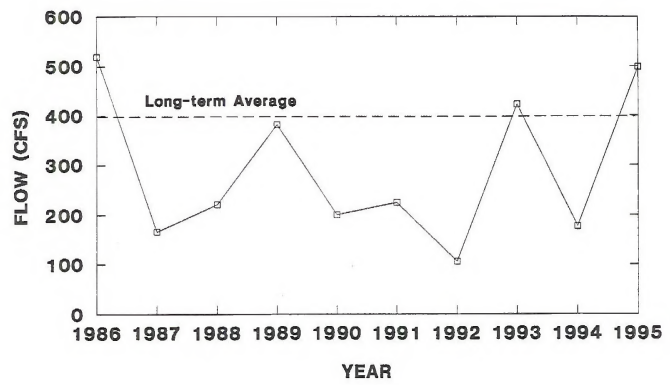


Table 4. Fish species observed during snorkel surveys of the West Fork Jarbidge River drainage, 1994.

\begin{tabular}{|c|c|c|c|c|c|c|c|c|c|}
\hline \multirow{2}{*}{ Site Number } & \multicolumn{9}{|c|}{ Fish Species Observed at each Sample Site } \\
\hline & $\mathrm{BT}^{1}$ & RBT & RT & MW & BS & SD & LD & RSS & MS \\
\hline \multicolumn{10}{|c|}{ West Fork Jarbidge River } \\
\hline WF1 & & $\mathbf{x}$ & & $\mathrm{x}$ & & & & & \\
\hline WF2 & & $\mathrm{x}$ & & & & & & $\mathbf{x}$ & $\mathrm{x}$ \\
\hline WF2A & & $\mathrm{x}$ & $\mathbf{x}$ & $\mathbf{x}$ & & & & $\mathrm{x}$ & \\
\hline WF3 & & $\mathrm{x}$ & $\mathbf{x}$ & & & & & & \\
\hline WF4 & & $\mathrm{x}$ & $x$ & $\mathbf{x}$ & & & & & $\mathrm{x}$ \\
\hline WF5 & & $\mathrm{x}$ & $\mathrm{x}$ & $\mathrm{x}$ & $\mathrm{x}$ & & & & \\
\hline WF5A & & $x$ & $\mathrm{x}$ & $\mathbf{x}$ & $x$ & $\mathrm{x}$ & & $\mathrm{x}$ & \\
\hline WF6A & & $\mathrm{x}$ & $\mathrm{x}$ & $\mathbf{x}$ & & & & $\mathrm{x}$ & \\
\hline WF6B & & $\mathrm{x}$ & & $\mathrm{x}$ & & & & $\mathrm{x}$ & \\
\hline WF6C & $\mathbf{x}$ & $\mathrm{x}$ & & $x$ & & & & & $x$ \\
\hline WF7A & & $\mathrm{x}$ & & $x$ & & & & & \\
\hline WF7B & & $\mathrm{x}$ & & & & & & $\mathrm{x}$ & \\
\hline WF7C & & $\mathrm{x}$ & $\mathbf{x}$ & $\mathbf{x}$ & $\mathbf{x}$ & $\mathrm{x}$ & & $\mathrm{x}$ & $\mathbf{x}$ \\
\hline WF8 & & $x$ & $\mathrm{x}$ & & & $x$ & & $\mathrm{x}$ & $\mathrm{x}$ \\
\hline WF9 & & $\mathrm{x}$ & $x$ & $x$ & & & & & \\
\hline WF10A & & $\mathrm{x}$ & $x$ & $x$ & & $x$ & & $\mathrm{x}$ & \\
\hline WF10B & & $\mathrm{x}$ & $x$ & $x$ & & $\mathrm{x}$ & & $x$ & \\
\hline WF10C & & $x$ & $\mathrm{x}$ & $x$ & & & & $\mathrm{x}$ & \\
\hline WF10D & & $x$ & $\mathrm{x}$ & $x$ & & & & & \\
\hline WF11 & & $\mathrm{x}$ & & $x$ & & & & $\mathrm{x}$ & $x$ \\
\hline WF12A & & $x$ & $x$ & $x$ & & & & $x$ & \\
\hline WF12B & & $\mathrm{x}$ & $x$ & $x$ & & & & $\mathrm{x}$ & \\
\hline WF13 & & $x$ & $x$ & $\mathbf{x}$ & & $\mathrm{x}$ & & $\mathrm{x}$ & \\
\hline WF14A & & $\mathrm{x}$ & $\mathrm{x}$ & & & & & $\mathrm{x}$ & $x$ \\
\hline WF14B & & $\mathrm{x}$ & $\mathrm{x}$ & $x$ & & & & $\mathrm{x}$ & \\
\hline WF15 & & $x$ & $\mathrm{x}$ & $x$ & & & & & $x$ \\
\hline \multicolumn{10}{|l|}{ Jack Creek } \\
\hline $\mathrm{JC} 1$ & $\mathbf{x}$ & $x$ & & $\mathbf{x}$ & & & & & \\
\hline
\end{tabular}


Table 5. Fish species observed during snorkel surveys of the Jarbidge and East Fork Jarbidge River drainage, 1994.

\begin{tabular}{|c|c|c|c|c|c|c|c|c|c|}
\hline \multirow{2}{*}{$\begin{array}{c}\text { Site } \\
\text { Number }\end{array}$} & \multicolumn{9}{|c|}{ Fish Species Observed at each Sample Site } \\
\hline & $\mathrm{BT}^{1}$ & RBT & RT & MW & $\mathrm{BS}$ & SD & LD & RSS & MS \\
\hline \multicolumn{10}{|c|}{ Jarbidge River } \\
\hline JR1 & & $x$ & & $\mathrm{x}$ & $\mathrm{x}$ & $\mathrm{x}$ & & $\mathrm{x}$ & $x$ \\
\hline $\mathrm{JR} 2$ & & $\mathrm{x}$ & & $\mathrm{x}$ & $x$ & $\mathrm{x}$ & $\mathrm{x}$ & $x$ & \\
\hline JR3 & & $\mathrm{x}$ & & $\mathbf{x}$ & $\mathrm{x}$ & $\mathrm{x}$ & $x$ & $\mathrm{x}$ & \\
\hline JR4 & & $\mathrm{x}$ & & $x$ & & $\mathrm{x}$ & & $x$ & \\
\hline JR5 & & $x$ & & $x$ & $x$ & $\mathrm{x}$ & & $x$ & \\
\hline \multicolumn{10}{|c|}{ East Fork Jarbidge River } \\
\hline $\mathrm{EF} 1$ & & $\mathrm{x}$ & & $x$ & & $\mathrm{x}$ & & & $x$ \\
\hline EF2 & & $x$ & & $x$ & $x$ & & & & $x$ \\
\hline EF3 & & $x$ & & $x$ & $x$ & $x$ & & & $x$ \\
\hline EF4 & & $x$ & & $x$ & $x$ & & & $x$ & $x$ \\
\hline $\mathrm{EF} 4 \mathrm{C}$ & & $x$ & & $\mathrm{x}$ & & & $x$ & & \\
\hline EF4B & & $x$ & & $x$ & & & & & $x$ \\
\hline EF4A & & $x$ & & $x$ & & & $x$ & & \\
\hline EF5 & & $x$ & & $x$ & & $x$ & $x$ & & \\
\hline EF6 & & $x$ & & $x$ & & & & & \\
\hline EF7 & & $x$ & & & & & & & \\
\hline EF8 & & $x$ & & & & & & & \\
\hline EF9 & & $x$ & & $\mathrm{x}$ & & & & & $x$ \\
\hline EF10A & & $x$ & & $x$ & & & & & $x$ \\
\hline EF10B & & $x$ & & $x$ & & & & & \\
\hline \multicolumn{10}{|c|}{ Dave Creek } \\
\hline $\mathrm{DC} 1 \mathrm{~A}$ & & $x$ & & & & & & & \\
\hline DC1B & & $\mathrm{x}$ & & & & & & & \\
\hline $\mathrm{DC} 1 \mathrm{C}$ & & $\mathrm{x}$ & & & & & & & \\
\hline DC1D & & $x$ & & & & & & & \\
\hline $\mathrm{DC} 2 \mathrm{~A}$ & & $x$ & & & & & & & \\
\hline $\mathrm{DC} 2 \mathrm{~B}$ & & $x$ & & & & & & & \\
\hline $\mathrm{DC} 2 \mathrm{C}$ & & $x$ & & & & & & & \\
\hline $\mathrm{DC} 2 \mathrm{D}$ & & & & & & & & & \\
\hline DC2E & & $\mathrm{x}$ & & & & & & & \\
\hline $\mathrm{DC} 2 \mathrm{~F}$ & & $x$ & & & & & & & \\
\hline
\end{tabular}

${ }^{1}$ Species codes: BT - bull trout, RBT - redband trout, RT - rainbow trout, MW - mountain whitefish, BS - bridgelip sucker, SD - speckled dace, LD - longnose dace, RSS - red-sided shiner, MS - mottled sculpin 
Deer Creek in 1995, also had redband trout present. At least four age classes of redband trout were observed in the East and West Forks of the Jarbidge River.

The West Fork of the Jarbidge had $250-275 \mathrm{~mm}$ long rainbow trout in many of the pools surveyed, which we assumed to be of hatchery origin due to tattered fins, similar size, and lack of white leading edges on the posterior fins. The Nevada Division of Wildlife (NDOW) plants 'catchable' hatchery rainbow trout in the West Fork of the Jarbidge River (Gary Johnson, NDOW, pers. comm.). Hatchery rainbow trout were observed $4 \mathrm{~km}$ into Idaho downstream of the Nevada state line.

Mountain whitefish were present in over one-half of the pools surveyed. Other species observed included speckled dace, longnose dace (Rhinichthys cataractae), redsided shiner (Richardsonius balteatus), bridgelip sucker, and sculpins (probably mottled sculpins) (Tables 4 and 5). No fish species other than redband trout were observed in Deer Creek in 1995.

In 1994-95, we estimated redband trout densities on two segments of Deer Creek and two segments on the West Fork of the Jarbidge River near the Jarbidge Mountain Wilderness boundary while surveying for bull trout by snorkeling (Table 6). Redband trout densities in Deer Creek and the upper West Fork were at the upper range of redband densities observed in the lower portions of the drainage on the mainstem and East and West Forks of the Jarbidge River (Warren and Partridge 1993). Stream widths of the segments we snorkeled to estimate redband density were significantly narrower than those sampled further downstream in the drainage (Table 6).

Table 6. Redband trout densities in Deer Creek on lands managed by U.S. Bureau of Land Management and in the West Fork Jarbidge River at the Jarbidge Mountain Wilderness Area boundary, 1994-95.

\begin{tabular}{llcccc}
\hline Stream & $\begin{array}{c}\text { Habitat } \\
\text { Type }\end{array}$ & $\begin{array}{c}\text { Length } \\
\text { Sampled (m) }\end{array}$ & $\begin{array}{c}\text { Stream } \\
\text { Width (m) }\end{array}$ & $\begin{array}{c}\text { Population } \\
\text { Estimate }\end{array}$ & $\begin{array}{c}\text { Density } \\
\text { (fish/100 } \mathrm{m}^{2} \text { ) }\end{array}$ \\
\hline Deer Creek & Riffle/Pool & 40.9 & 3.4 & 21 & 15.5 \\
& Pool & 61.3 & 2.9 & 40 & 19.8 \\
W. Fork Jarbidge & Riffle/Pool & 74.4 & 4.1 & 53 & 17.4 \\
& Pool & 37.1 & 4.0 & 35 & 23.6 \\
\hline
\end{tabular}

Pool Measurements.-- Maximum depths of pools surveyed on the East and West Forks of the Jarbidge River averaged 0.9 and $1.0 \mathrm{~m}$, respectively (Table 7). Generally, suitable cover such as large boulders, woody debris, undercut banks was present in pools in these streams providing good habitat for bull trout. Maximum pool depths in Deer and Dave Creeks were significantly 
Table 7. Average width, length, and depths of pools of streams surveyed for the presence of bull trout in the middle Jarbidge River drainage, 1994-95.

\begin{tabular}{|c|c|c|c|c|c|c|c|c|c|}
\hline \multirow[t]{2}{*}{ Stream } & \multicolumn{2}{|c|}{$\begin{array}{c}\text { Pool } \\
\text { Width (m) }\end{array}$} & \multicolumn{2}{|c|}{$\begin{array}{c}\text { Pool } \\
\text { Length }(m)\end{array}$} & \multicolumn{2}{|c|}{$\begin{array}{l}\text { Maximum } \\
\text { Depth (m) }\end{array}$} & \multicolumn{2}{|c|}{$\begin{array}{l}\text { Residual } \\
\text { Depth (m) }\end{array}$} & \multirow[t]{2}{*}{$n$} \\
\hline & $\bar{x}$ & SE & $\bar{x}$ & SE & $\bar{x}$ & $\mathrm{SE}$ & $\bar{x}$ & SE & \\
\hline Jarbidge River & 12.9 & 0.63 & 39.7 & 5.02 & - & & - & & 5 \\
\hline W. Fork Jarbidge & 7.6 & 0.27 & 17.0 & 1.33 & 1.0 & 0.09 & 0.7 & 0.09 & 26 \\
\hline E. Fork Jarbidge & 8.7 & 0.59 & 22.5 & 2.54 & 0.9 & 0.06 & 0.6 & 0.07 & 14 \\
\hline Dave Creek & 2.2 & 0.24 & 6.5 & 1.80 & 0.3 & 0.03 & 0.2 & 0.03 & 10 \\
\hline Deer Creek & 2.9 & 0.28 & 6.8 & 1.54 & 0.5 & 0.03 & 0.2 & 0.04 & 9 \\
\hline
\end{tabular}

less than in the East and West Forks. Because of the small size of the pools in these two tributary streams (Table 7), these drainages are likely migratory corridors rather than seasonal habitats for the migratory population of bull trout in the Jarbidge drainage. Resident bull trout were present in the headwaters of Dave Creek, but were not found during surveys of 5 sample sites in Deer Creek on the Humboldt National Forest in 1992 (NDOW, unpublished data).

In summer 1994, we observed that the road culvert at Jack Creek was replaced during the fall of 1993, and was probably impassable to fish. Average water velocity (measured with an orange) in the culvert on July 7, 1994 was approximately $2.4 \mathrm{~m}$ per second. The culvert was 18.3 $\mathrm{m}$ long and $1.8 \mathrm{~m}$ in diameter and had a $0.69 \mathrm{~m}$ drop from the downstream end of the culvert to the plunge pool below. By August 1995, the culvert was a complete barrier to fish passage. The drop from the end of the culvert to the pool had increased to $1.0 \mathrm{~m}$ with $1.2 \mathrm{~m}$ of streambed of large cobbles and small boulders between the culvert outflow and the edge of the plunge pool.

\section{Discussion}

Migratory bull trout are still present in the Jarbidge River drainage. Warren and Partridge (1993) likely did not observe any bull trout in the Idaho portion of the Jarbidge River in 1992 because the fish had already moved to higher elevations (and more suitable water temperatures) in the drainage at the time of their surveys. In fact, one bull trout was observed moving upstream in the East Fork below Murphy Hot Springs in early summer 1992 (Mark Vinson, BLM, pers. comm.) before the IDFG surveys were initiated. Our July 1994 surveys were conducted when water temperatures in the lower to mid-portions of the Jarbidge drainage were quickly increasing to unsuitable levels for bull trout. Bull trout are thought to not tolerate water temperatures much beyond 16 to 17 degrees $C$ (Russ Thurow, USFS, pers. comm.). The largest bull trout that has been caught in the Jarbidge River in Nevada was $550 \mathrm{~mm}$ long (Gary Johnson, NDOW, pers. 
comm.), which only could have reached that size utilizing a migratory life history. In addition to the bull trout observed during this inventory, IDFG observed a bull trout at the confluence of the East and West Forks of the Jarbidge River in October 1994, while retrieving a thermograph (Fred Partridge, IDFG, pers. comm.).

From the 1994 surveys, we detected 5 bull trout $/ \mathrm{km}$ of stream for the East and West Forks of the Jarbidge. This is probably a minimum population estimate for the migratory portion of the bull trout population in the Jarbidge drainage, because most fish probably had moved upstream of the portions of the drainage we sampled with water temperatures of 16-17 degrees $C$ at the time of the surveys. The majority of the bull trout we observed were below a barrier on Jack Creek that at least delayed fish movement and possibly completely blocked passage. We did not detect any fish in the East Fork of the Jarbidge River and they probably had already moved upstream of the reach we sampled. If this had occurred, then the 1994 sampling would give a minimum population estimate for the migratory population of bull trout of 10.6 fish $/ \mathrm{km}$ of stream. This is considerably smaller than population estimates for resident bull trout populations in the upper portions of the East and West Forks, but similar to the estimates for the middle portions of the East and West Fork Jarbidge River drainages (Table 8).

Table 8. Population estimates for bull trout in the middle and upper headwater areas of the West and East Forks of the Jarbidge River in Nevada, 1954-1993'.

\begin{tabular}{llrrrr}
\hline \multirow{2}{*}{ Drainage } & \multicolumn{1}{c}{ Stream } & \multirow{2}{*}{ Elevation $(\mathrm{m})$} & \multicolumn{3}{c}{ Population Estimate } \\
\cline { 4 - 6 } & & & Eish/km & \multicolumn{1}{c}{ SE } & n \\
\hline \multirow{2}{*}{ W. Fork Jarbidge } & W. Fork Jarbidge & $1792-1975$ & 20.9 & 2.8 & 4 \\
& Jack Creek & $1883-1926$ & 51.5 & 1.5 & 2 \\
& W. Fork Headwaters & $2146-2252$ & 125.8 & 39.3 & 4 \\
E. Fork Jarbidge & E. Fork Jarbidge & $1801-1935$ & 12.8 & 3.5 & 2 \\
& Dave Creek & $2164-2304$ & 82.5 & 16.3 & 2 \\
& Slide Creek & $2082-2252$ & 143.1 & 58.2 & 3 \\
& E. Fork Headwaters & $2188-2303$ & 52.7 & 23.1 & 3 \\
\hline
\end{tabular}

${ }^{1}$ Data from Johnson (1990) and Gary Johnson, NDOW (unpubl. data).

The 1994 sampling was conducted after 6 out of 8 years of significantly below average river flows (Fig. 5), including the lowest flows on record for the Bruneau-Jarbidge drainage in 1992. With drought flows, stream temperatures increase more quickly than usual in spring, causing bull trout to move upstream sooner. Thus, less habitat was available seasonally to the migratory population of bull trout. Therefore, bull trout numbers at the time of the surveys may have been lower than during more typical periods of river flows. 
The culvert at Jack Creek is now a complete barrier to fish passage. Before the new culvert was placed in 1993, older versions had blocked fish passage. The culvert was identified as a passage barrier in July 1981 when the stream was inventoried by BLM personnel. The Nevada Division of Wildlife resurveyed the plunge pool below the culvert on September 28, 1994 and did not find any bull trout (Gary Johnson, NDOW, pers. comm.). The stream temperature was 9.4 degrees $\mathrm{C}$ at 1250 hours when they resampled the pool.

At the Jarbidge River Bull Trout Task Force Meeting in February 1994, a local resident reported a large shift in species composition of fish caught in Jack Creek after the culvert was installed from bull trout dominating in the creel to one bull trout now caught for every nine rainbow (redband) trout (Phil Joyal, pers. comm.). He also reported large bull trout were often caught in the pool below the culvert after it was installed.

\section{Management Implications}

The 1994 surveys for bull trout identified the fish passage problem at Jack Creek. The Bull Trout Task Force is working on short-term and long-term solutions (replacing the culvert with a bridge) to allow migratory bull trout to move up and down Jack Creek. Participants in the Bull Trout Task Force include the BLM, Humboldt National Forest, NDOW, USFWS, Elko County in Nevada, and interested local citizens. The goal of the Task Force is to improve habitat conditions and remove threats to bull trout in the Jarbidge River. The Task Force plans to replace the Jack Creek culvert in 1997. This passage barrier is the greatest problem identified currently for the maintenance of bull trout populations in the Jarbidge drainage. For the short term, NDOW is planning on moving fish found below the culvert to upstream of this fish barrier.

The snorkel surveys were successful in determining that the migratory segment of the bull trout population was still present in the Jarbidge drainage. However, additional information on bull trout distribution is needed to be able to effectively monitor and manage bull trout in the drainage (Rieman and McIntyre 1993). Snorkel surveys should be conducted to determine the lower distribution of resident bull trout in the Jarbidge drainage. Rieman and McIntyre (1985) thought bull trout were resident in streams in the Boise River drainage in Idaho down to an elevation of $1600 \mathrm{~m}$. Resident bull trout do not appear to be distributed below $1800 \mathrm{~m}$ in the Jarbidge drainage (Table 8), but surveys should be conducted when migratory bull trout are not at lower elevations than those inhabited by resident fish to establish the distributional limits of resident fish in the drainage. Additionally, snorkel surveys should be conducted in tributary streams to the East and West Forks of the Jarbidge River to determine the number of streams in the drainage currently supporting bull trout populations. The advantage of snorkel surveys is that a significantly greater amount of stream can be surveyed for presence/absence of bull trout per unit of time compared to electrofishing sampling. These snorkel surveys would complement electrofishing sampling conducted by NDOW to estimate population sizes. 
Rieman and McIntyre (1993) recommended developing estimates of the relative abundance of bull trout in a drainage basin after determining their distribution. Establishing standardized inventories and monitoring of bull trout populations was also recommended by IDFG in their bull trout management plan (IDFG 1993). The migratory population of bull trout in the Jarbidge River should be monitored by placing a temporary weir at the confluence of the East and West Forks of the Jarbidge to count migratory bull trout as they move downstream in the fall after spawning in late August and September. If possible the weir should be located to count fish moving down both the East and West Forks, especially during initial monitoring periods, because snorkel surveys did not confirm migratory bull trout were in the East Fork in 1994. Population monitoring should be repeated over a period of years to determine population trends. The migratory population should particularly be monitored to determine responses to the planned removal of the fish passage barrier on Jack Creek and to examine if bull trout numbers declined during drought flows from 1987-1992.

\section{Acknowledgments}

We thank Russ Thurow for training us in snorkel techniques to survey for bull trout and assisting with the initial surveys. Trish Klaar helped us conduct surveys in 1995. Matt McCoy prepared the figures and created GIS databases.

\section{Literature Cited}

Behnke, R. J. 1992. Native trout of western North America. American Fisheries Society Monograph 6.

IDFG. 1993. Bull trout management plan (Draft). Idaho Dept. of Fish and Game. $11 \mathrm{pp.}$

Johnson, G.L. 1990. Bull trout species management plan. State of Nevada, Department of Wildlife, Statewide Fisheries Program, Federal Aid Project No. F-20-26, Job No. 207.4. $17 \mathrm{pp}$.

Rieman, B.E. and J.D. McIntyre. 1995. Occurrence of bull trout in naturally fragmented habitat patches of varied size. Trans. American Fisheries Soc. 124:285-296.

Rieman, B.E. and J.D. McIntyre. 1993. Demographic and habitat requirements for conservation of bull trout. Gen. Tech. Rep. INT-302. Ogden, UT: U.S. Department of Agriculture, Forest Service, Intermountain Research Station. 38 pp.

Rode, M. 1988. Bull trout, Salvelimus confluentus, (Suckley), in the McCloud River, status and recovery recommendations. Inland Fish. Admin. Rep. Sacramento, CA: California Department of Fish and Game. 43 pp. 
Thurow, R.F. 1994. Underwater methods for study of salmonids in the Intermountain West. Gen. Tech. Rep. INT-GTR-307. Ogden, UT: U.S. Department of Agriculture, Forest Service, Intermountain Research Station. 28 pp.

Warren, C.D. and F.E. Partridge. 1993. Evaluation of the status of bull trout in the Jarbidge River drainage, Idaho. Idaho BLM Technical Bulletin No. 93-1, Idaho State Office, BLM, Boise, Idaho. $20 \mathrm{pp}$.

Zippin, C. 1958. The removal method of population estimation. J. Wildl. Manage. 22:82-90. 
Appendix A. Universal Transverse Mecator grid coordinates for snorkel survey sites in the Jarbidge River Drainage.

\begin{tabular}{|c|c|c|c|}
\hline Site & X-UTM & Y-UTM & COMMENTS \\
\hline JR1 & 632105 & 4658310 & $1.3 \mathrm{mi}$ downstream of confluence of 2 forks \\
\hline $\mathrm{JR} 2$ & 632220 & 4658155 & pool just below large woody debris jam \\
\hline JR3 & 632660 & 4657720 & first large pool downstream of old footbridge foundation \\
\hline JR4 & 633040 & 4656865 & about $0.25 \mathrm{mi}$ downstream of confluence of the 2 forks \\
\hline JR5 & 633090 & 4656680 & just above stream mile 25 \\
\hline WF1 & 632900 & 4655570 & $0.6 \mathrm{mi}$ upstream of bridge at the confluence of the 2 forks \\
\hline F2 & 632440 & 4654780 & pool complex $1.1 \mathrm{mi}$ up from bridge \\
\hline WF2A & 632205 & 4654340 & $1.6 \mathrm{mi}$ up from bridge \\
\hline $\mathrm{F} 3$ & 632030 & 4653960 & $1.8 \mathrm{mi}$ up from bridge \\
\hline F4 & 631950 & 4653850 & $1.9 \mathrm{mi}$ up from bridge \\
\hline WF5 & 631920 & 4653780 & 200 feet upstream of site 4 \\
\hline WF5A & 631740 & 4653450 & $2.1 \mathrm{mi}$ up from bridge \\
\hline WF6 & 631360 & 4652530 & complex of 3 pools about $0.45 \mathrm{mi}$ downstream of Buck Creek \\
\hline WF7 & 631520 & 4651170 & complex of 3 pools 0.45 mi upstream of Buck Creek bridge \\
\hline F8 & 631605 & 4650670 & first large pool downstream of ID-NV border \\
\hline F9 & 631620 & 4649710 & $0.45 \mathrm{mi}$ into Nevada at the first wide road turnout \\
\hline F10 & 631560 & 4648950 & pool-riffle complex with 3 pools, $0.85 \mathrm{mi}$ into Nevada \\
\hline F 11 & 631560 & 4648620 & wood debris and bedrock scour pool, $1.1 \mathrm{mi}$ into Nevada \\
\hline WF12 & 631590 & 4647770 & 2 pool complex, pool B-mid-channel boulder scour pool \\
\hline WF13 & 631600 & 4646900 & scour/plunge pool associated with a log jam, $2.25 \mathrm{mi}$ into NV \\
\hline WF14 & 631440 & 4646420 & 2 step pools at rock face along road, $2.75 \mathrm{mi}$ into Nevada \\
\hline WF15 & 630640 & 4641045 & 100 yards downstream of Jack Creek confluence \\
\hline $\mathrm{JCl}$ & 630710 & 4641010 & plunge pool below culvert \\
\hline $\mathrm{DRC1}$ & 629910 & 4642150 & riffle-pool complex \\
\hline $\mathrm{DRC} 12$ & 629780 & 4641970 & single pool \\
\hline EF1 & 634130 & 4655430 & $0.85 \mathrm{mi}$ upstream of forks confluence at a room-sized boulder \\
\hline $\mathrm{F} 2$ & 634310 & 4655265 & $0.95 \mathrm{mi}$ upstream of recreation site at confluence of 2 forks \\
\hline F3 & 635120 & 4654530 & outside meander pool against road bend, 1.75 mi upstream \\
\hline EF4 & 635450 & 4654030 & $2.175 \mathrm{mi}$ upstream of recreation site at forks confluence \\
\hline EF4A & 636700 & 4651930 & wood jam pool about $150 \mathrm{~m}$ downstream of powerlines \\
\hline EF4B & 636780 & 4651670 & lateral wood (juniper snag) scour pool, $200 \mathrm{~m}$ above powerline \\
\hline EF4C & 636640 & 4651180 & mid-channel boulder scour pool, about $0.5 \mathrm{mi}$ above powerline \\
\hline EF5 & 636620 & 4650985 & near 2nd major draw on east side of canyon above Murphy \\
\hline EF6 & 636530 & 4650720 & about $0.8 \mathrm{mi}$ upstream of powerlines \\
\hline EF7 & 636530 & 4650430 & 200 feet below Dave Creek confluence \\
\hline EF8 & 636530 & 4650380 & 20 feet below Dave Creek confluence \\
\hline EF9 & 639010 & 4646685 & downstream of Cougar Point Creek about 100 feet \\
\hline 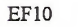 & 639040 & 4646600 & 150 feet upstream of Cougar Point Creek confluence \\
\hline
\end{tabular}


Appendix A (cont.)

Site X-UTM Y-UTM COMMENTS

DC1 $635090 \quad 46483604$ pools just upstream of drainage off Wilkins Island

DC2 $635210 \quad 46470006$ pools 2.2 to 2.45 mi upstream of Nevada border 


\section{BLM LIBRARY \\ BLDG 50, ST-150A \\ DENVER FEDERAL CENTER \\ P.O. BOX 25047 \\ DENVER, COLORADO 80225}

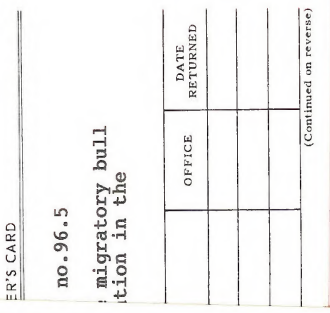

QL 84.2 .L 352 no. 96.5

88055062

Status of the migratory bull

trout population in the

BLDG 50, ST-150A

DENVER FEDERAL CENTER

P.O. BOX 25047

DENVER, COLORADO 80225 